\title{
Native palms as an economically important non- timber forest product among rural communities in the Yucatán peninsula, Mexico
}

\author{
Noguera-Savelli, Eliana ${ }^{1 *}$; Cetzal-Ix, William ${ }^{2}$ \\ 1 Consejo Nacional de Ciencia y Tecnología, Colegio de Postgraduados Campus Campeche, Champotón, \\ Campeche, México, C. P. 24450. \\ 2 Tecnológico Nacional de México, Instituto Tecnológico de Chiná, Chiná, Campeche, México, C. P. 24520. \\ * Correspondence: eliananoguera@gmail.com
}

Citation: Noguera-Savelli, E., Cetzal-Ix, W. (2021). Native palms as an economically important nontimber forest product among rural communities in the Yucatán peninsula, Mexico. Agro Productividad. https://doi. org/ 10.32854/agrop.vl4il1.2007

Editor in Chief: Dr. Jorge Cadena Iñiguez

Received: April 26, 2021. Accepted: October 29, 2021.

Published on-line: December 1, 2021

This work is licensed under a Creative Commons Attribution-NonCommercial 4.0 International license.

\section{ABSTRACT}

Objective. To analyze the valuation, use, and preservation of native palms as a non-timber forest product (NTFP) of high economic importance for rural communities in the Yucatán Peninsula, Mexico.

Design/methodology/approach: The available literature on palms and their use in the Yucatán Peninsula (YP) was examined using the snowball method. Subsequently, different online flora databases were consulted in order to examine the taxonomic identities of palm species present in the YP. The reported uses were classified.

Results: The YP has 20 native species that belong to 13 genera and three subfamilies. All of them are economically exploited as NTFPs, especially in construction (85\%) and honey production (70\%), followed by food and medicinal use (35\% each), craftwork (30\%), ornamental use $(25 \%)$, and fodder $(10 \%)$. These data confirm that native palms are an important livelihood means for the inhabitants of Mayan communities in the region.

Study limitations/implications: The research faced a limited database of encyclopedias, anthologies, directories, books, or articles that interpret works or research about this topic.

Findings/Conclusions: The local and regional use of palms represents an additional income for the people who use this natural resource on different productive scales, both in rural communities and city centers. An alternative to ensure the sustainability of palms would be to establish governmental programs for their reproduction.

Key words: Arecaceae, Uses, Construction, Campeche, Quintana Roo, Yucatán.

\section{INTRODUCTION}

The species that belong to the Arecaceae or Palmae family are commonly known as palms. They make up over 2,400 species of cosmopolitan distribution, comprised in 183 genera and five subfamilies (Dransfield et al., 2008). Palms are classified as part of the monocotyledons and are characterized by morphological traits such as generally nonramified woody stems and generally composite large leaves that form a crest at the tip

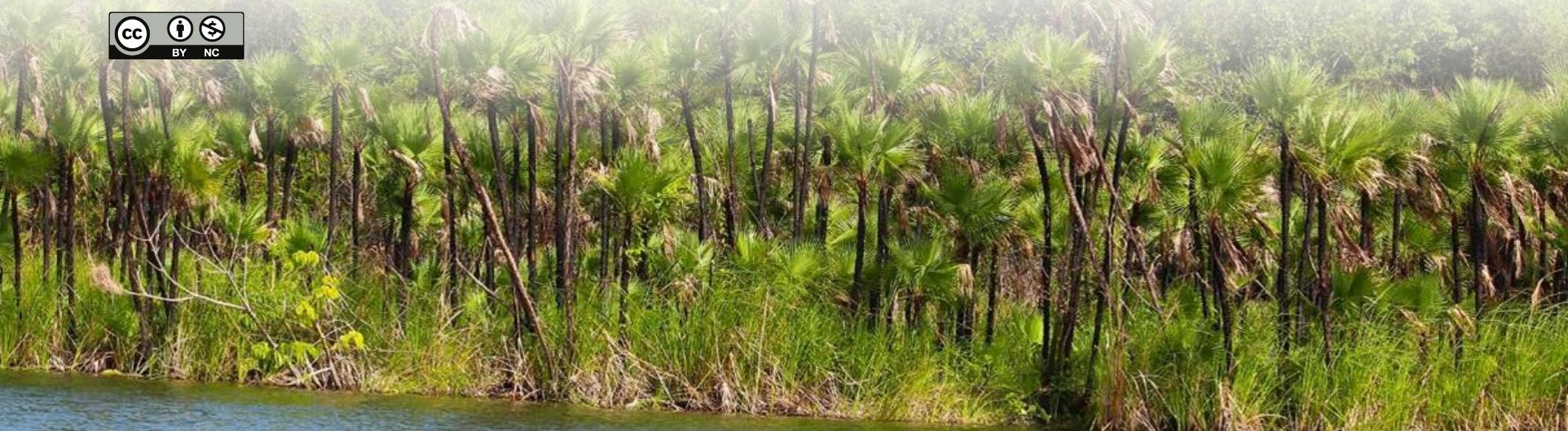


(Alvarado-Segura et al., 2012). Palms are distributed in the tropics and subtropics (0-3,200 masl), mainly in tropical rain forests (Dransfield et al., 2008; Galeano and Bernal, 2010). The diversity of their life forms and their abundance in the canopy or the understory have made them ecologically relevant elements for the function of some ecosystems. For this reason, they have been used in the tropics as a model for the study of the diversity of species, their causes, and maintenance (Quero and Flores, 2004; Dransfield et al., 2008; Alvarado-Segura, 2014). Human beings have used palms as a source of natural resources for thousands of years; different cultures have used them as a non-timber forest product (PFNM), as well as for food, oils, fibers, medicines, construction materials, and other uses (Pérez-García and Rebollar-Domínguez, 2008). Gurrently, their ornamental value contributes to the economy of several countries and to the lifestyle of their inhabitants (Quero and Flores, 2004). In Mexico, the exploitation of the flora as a social practice is mainly carried out in rural areas (Challenger, 1998); in this regard, the country registers around 100 species of native palms, comprised in 22 genera and three subfamilies (Quero and Flores, 2004). In the Yucatán Peninsula (YP), rural communities exploit a wide variety of vegetable species, including palms. They are economically important, because all their species are widely used in the population's livelihood (de la Torre et al., 2009). This study consists of a thorough bibliographic review of sources about the potential of palms as a non-timber forest product, in order to encourage their knowledge, preservation, and the appreciation of the goods and services they provide to both ecosystems and human beings in the YP, Mexico.

\section{MATERIALS AND METHODS}

First of all, the available literature on palms and their use in the YP (which comprises the states of Campeche, Quintana Roo, and Yucatán) was reviewed using the snowball method (Bernard, 2006). Subsequently, several online flora databases were consulted in order to examine the taxonomic identities of the palm species found in the YP. Some of these databases included: Tropicos ${ }^{\circledR}$ (www.w3tropicos.org); Flora: Península de YucatánGICY (https://www.cicy.mx/sitios/flora\%20digital/); The Plant List (www.theplantlist. org); and the International Plant Names Index (www.ipni.org). Based on the information that was gathered, the uses of palms were classified as follows: 1) food; 2) fodder (used to feed livestock); 3) craftworks (used to make tools and decorative objects); 4) construction (used to build traditional housing, fences, etcetera); 5) medicinal uses (used to treat human health issues); 6) ornamental use (used to decorate public areas or private houses); 7) honey production (used as food in production activities for apiculture and meliponiculture). Based on the gathered information, descriptive analyses about the native palms of the YP were carried out and later documented with field photographs.

\section{RESULTS AND DISGUSSION}

Twenty native palm species grow in the YP (Table 1). They comprise 13 genera and three subfamilies: Acoelorrhaphe, Coccothrinax, Cryosophila, Thrinax, and Sabal (Coryphoideae); Acrocomia, Attalea, Bactris, Chamaedorea, Desmoncus, Gaussia, and Roystonea (Arecoideae); and Pseudophoenix (Ceroxyloideae) (Quero and Flores, 2004; Carnevali et al., 2010). These 


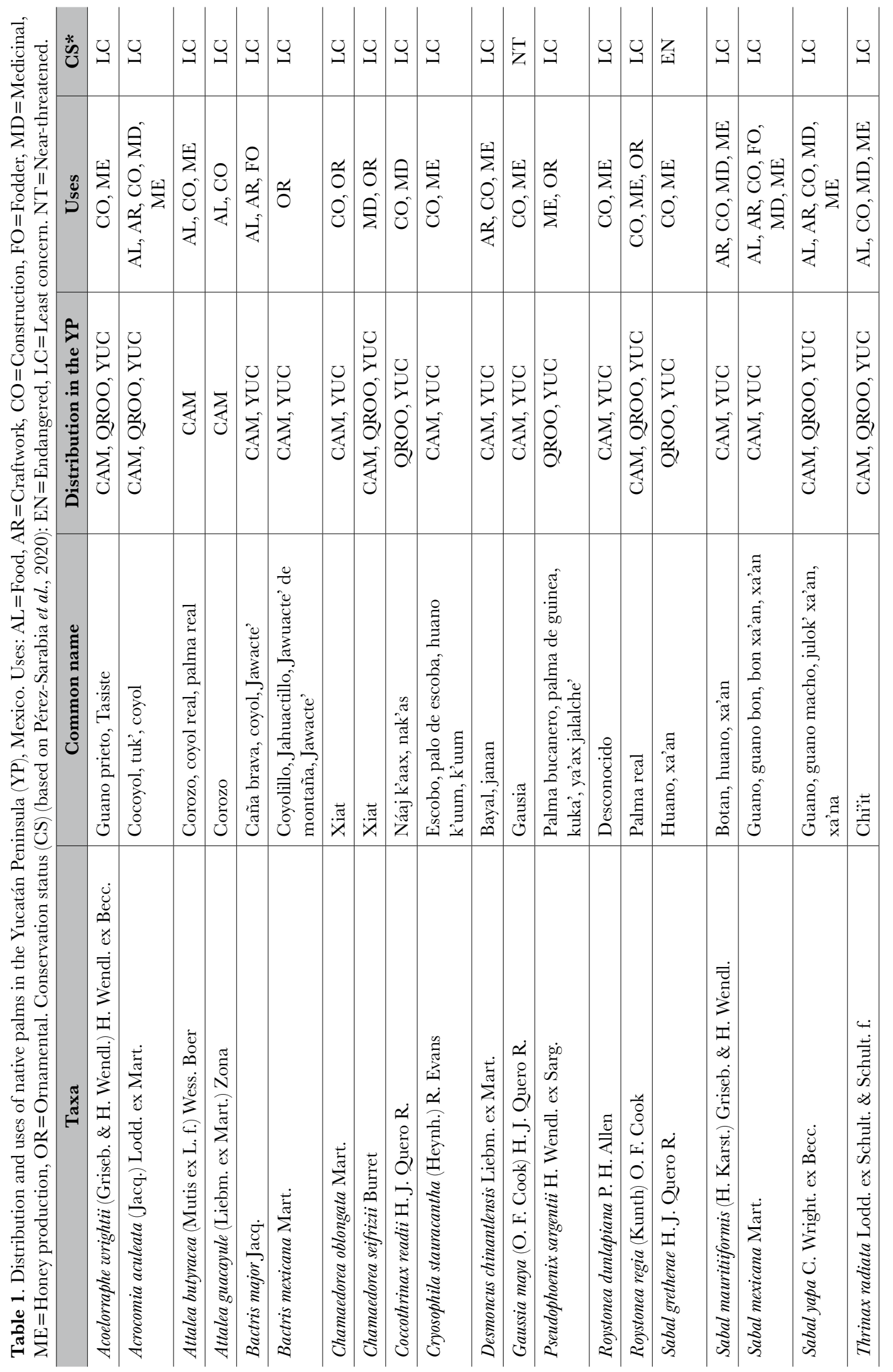


palms, found in the YP, are important or predominant floral elements in medium and high semi-evergreen tropical forests, subdeciduous tropical forests, and coastal sand dune scrubs (Miranda, 1958; Orellana, 1992; Sánchez and Islebe, 2002).

\section{Current and potential uses}

All native YP palms are exploited economically as non-timber forest product (NTFPs). They are predominantly used in construction (85\%) and honey production (70\%), followed by food and medicinal uses (35\% each), craftwork (30\%), ornamental use (25\%), and fodder (10\%) (Table 2). This confirms that palms are an important means of livelihood for the Mayan communities in the region. Two of the most widely used species are huano (Sabal mexicana) and $S$. yapa, which have been used since the times of the ancient Mayas (Martínez-Ballesté et al., 2008): these types of palms have been used for approximately more than 3,000 years to build roofs for houses, and also as food for humans and fodder (Pulido and Caballero, 2011). The widespread use of these two species led to the creation of the NOM-006-SEMARNAT-1997 (SEMARNAT, 1997), which establishes the procedures, criteria, and specifications for the exploitation, transport, and storage of palm leaves in natural environments in the Mexican territory. This regulation serves as a control measure for the exploitation of this NTFP, which is highly important for the livelihood of the inhabitants of the YP rural communities. According to interviews with key inhabitants of several YP towns (Tenabo, Hopelchén, Champotón, Calkiní in Campeche; Felipe Carrillo Puerto in Quintana Roo; Mérida and Maxcanú in Yucatán), the cost per cut leaf unit of the huano (Sabal) species fluctuates between one and five pesos, except for Iturbide, El Platanar, and other towns of the Hopelchén municipality, Campeche, where the huano leaf can be bought for 0.50 pesos. Palm leaves are sold by unit (leaf) or by roll. Thus, in Yucatán, 1 roll (50 palm leaves) costs 180 pesos; in the Tenabo municipality of Campeche, 1 roll (50-60 palm leaves) costs 80-100 pesos; meanwhile, in the Holpechén municipality, palm is only sold by leaf and costs between $0.50-1$ and 2-3 pesos, in Iturbide and Ukum, respectively. The exploitation of huano leaves in Campeche is an economic activity that represents a source of income for workers, whose daily wage (called jornal) can reach 200 pesos. Depending on its dimensions, building a roof for a traditional Mayan construction may require an investment of up to 6,000 pesos —only for the acquisition of the leaves (Figure 1).

Table 2. Use of native palms in the Yucatán Peninsula, Mexico.

\begin{tabular}{l|c|c}
\hline \multicolumn{1}{c|}{ Use } & Number of species & Percentage of use \\
\hline Construction & 17 & $85 \%$ \\
\hline Honey production & 14 & $70 \%$ \\
\hline Food & 7 & $35 \%$ \\
\hline Medicinal & 7 & $35 \%$ \\
\hline Craftwork & 6 & $30 \%$ \\
\hline Ornamental & 5 & $25 \%$ \\
\hline Fodder & 2 & $10 \%$ \\
\hline
\end{tabular}




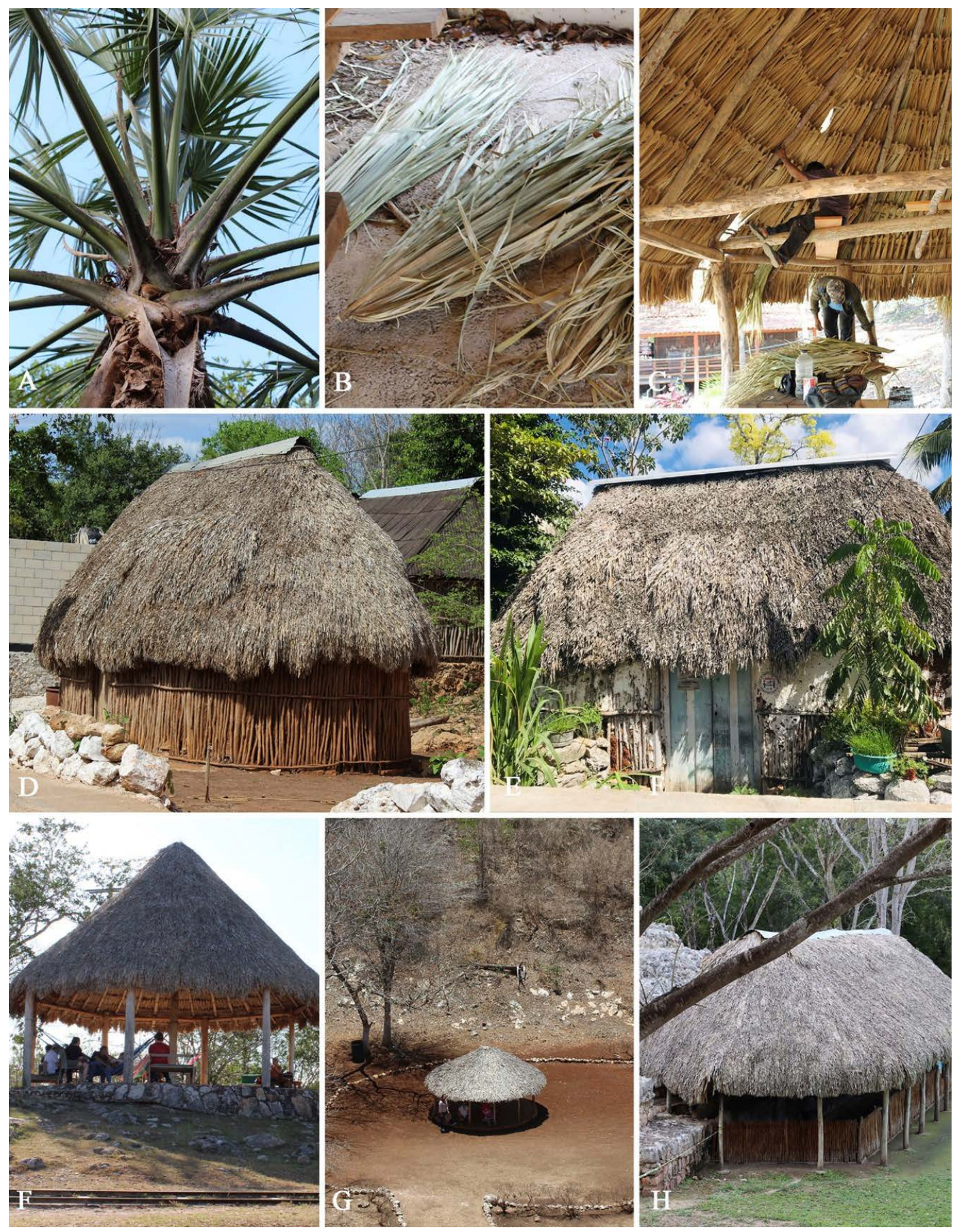

Figure 1. Uses of Sabal mexicana in the Yucatan Peninsula. A. Sabal mexicana. B. Huano Leaf. C. House construction. D-E. Houses with a huano roof. F. Palapa for tourism. G-H. Palapas to protect mayas stelae in archaeological zones.

At present, only some palm species have been spreading widely in the region, as a result of their ornamental potential. One of them is Roystonea regia, which is grown in most cities and piers, and whose wild populations are rare and little known. Governmental programs' nurseries should propose palms as a NTFP that can generate additional income, 
and have them certified in order to guarantee that their commercialization is fair and does not damage wild populations. Likewise, the Sabal yapa and S. mexicana species should be grown in deforested areas for their exploitation. In addition, the establishment of nurseries that use seeds to spread palm species with an ornamental potential — such as Gaussia maya, Chamaedora seifrizii, and C. oblongata - is feasible. This would also help their natural populations to remain unaltered.

\section{Distribution in the Yucatán Peninsula}

Some palm species have a limited distribution in the YP. Sabal gretherae, for instance, grows in a pasture sector of the northern area of Quintana Roo; Gaussia maya and Chamaedorea oblongata only grow in the southeastern end of the peninsula (Campeche and Quintana Roo); and Pseudophoenix sargentii generally forms small populations, with a discontinuous pattern along the coastal area of Yucatán and Quintana Roo (Quero and Flores, 2004). G. maya is endemic to the Yucatán Peninsula Biotic Province, while Coccothrinax readii and S. gretherae are endemic to the Mexican section of the Peninsula (Quero and Flores, 2004). In contrast, the remaining species are widely distributed in the region, as in the case of Acrocomia aculeata and Sabal yapa, which are apparently favored by disturbance conditions (Orellana 1992; Quero and Flores, 2004) (Figure 2).

\section{Conservation status}

According to the Official Mexican Standard (DOF, 2010), nine native palms of the YP are listed in a risk category: Coccothrinax readii, Cryosophila stauracantha, Gaussia maya, Pseudophoenix sargentii, and Thrinax radiate appear as endangered, while Bactris major, Roystonea dunlapiana, R. regia, and Sabal gretherae appear under special protection. However, according to Pérez-Sarabia et al. (2020), 18 out of the 20 species are listed under the category of least concern, one as near-threatened $(G$. maya), and the other one as endangered $(S$. gretherae). The main threat for these species is the loss of habitat as a consequence of the land use conversion for anthropogenic activities.

\section{CONGLUSION}

The different economic uses and the lack of planning for the adequate management of palms have led to several palm species being listed in preservation risk categories. The wild palm populations have been impacted by the exploitation of stems, leaves, and complete individuals linked to an excessive extraction rate. In addition, deforestation, extensive cattle farming, intensive agriculture, and tourism-related urbanization have reduced palm habitats to fragments of vegetation. The local and regional use of palms represents an additional income for people who use this natural resource on different productive scales, both in rural communities and city centers. An alternative to ensure the sustainability of palms would be to establish governmental programs to reproduce them on a large scale, through seeding in forest nurseries that would enable their sustainable use and the preservation of wild populations. 

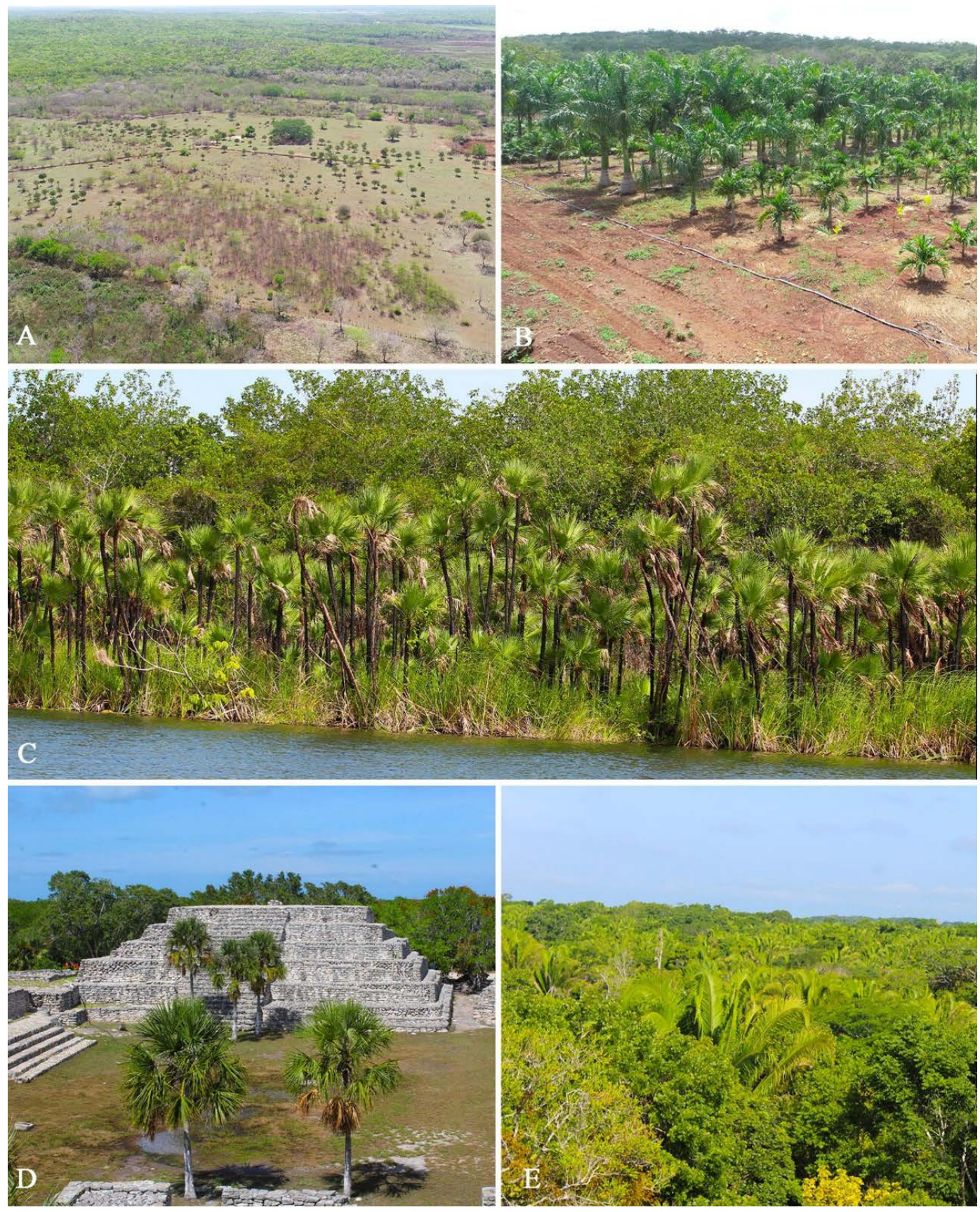

Figure 2. Arecaceae ecosystems in the Yucatan peninsula, Mexico. A. Deforested areas for crops where they keep Sabal mexicana in Hopelchén, Campeche. B. Cultivation of Roystonea regia in Xamantún, Campeche. C. Acoelorraphe wrightii in its natural habitat, Río Hondo, Quintana Roo. D. Sabal yapa populations conserved in the archaeological zone of Xtampú, Yucatán. E. Attalea guacayule populations conserved in the archaeological zone of Kohunlich, Quintana Roo.

\section{AGKNOWLEDGEMENTS}

The authors would like to thank the following projects: Cátedras CONAGyT No. 364 "Reconversión productiva sustentable para el desarrollo de los productores rurales de Campeche, México" and CONACyT (FORDECYT-PRONACES, \#304952) “Consolidación de la Unidad de Conservación de Flora Nativa de 
la Península de Yucatán: estrategia para integrar y promover el conocimiento etnobotánico con fines de investigación, formación de recursos humanos, conservación, uso y manejo sustentable”.

\section{REFERENGES}

Alvarado-Segura A.A., Calvo-Irabién L.M., Duno de Stefano R. \& Balslev H. (2012). Palm richness, abundance and diversity along an environmental gradient on the Yucatan Peninsula. Nordic Journal of Botany 30: 613-622.

Alvarado-Segura A.A. (2014). Patrones de diversidad en comunidades de palmas (Arecaceae) en selvas medianas de la Península de Yucatán: determinantes ambientales y espaciales. Tesis doctoral. Centro de Investigación Científica de Yucatán, A.C., Mérida, Yucatán, México.

Bernard H.R. (2006). Research methods in anthropology: qualitative and quantitative approaches, 4th edn. Library of Congress, Washington, DC.

Carnevali F.C.G., Tapia-Muñoz J.L., Duno de Stefano R. \& Ramírez-Morillo I. (editores generales). (2010). Flora Ilustrada de la Península de Yucatán: Listado Florístico. Centro de Investigación Científica de Yucatán A.C., Mérida Yucatán, México.

Challenger A. (1998). Utilización y conservación de los ecosistemas terrestres de México, pasado, presente y futuro de México. CONABIO, Instituto Biológico. UNAM: Agrupación Sierra Madre S. C. P., México.

de la Torre L., Calvo-Irabién L.M., Salazar C., Balslev H. \& Borchsenius F. (2009). Contrasting palm species and use diversity in the Yucatan Peninsula and the Ecuadorian Amazon. Biodiversity and Conservation 18, 2837-2853.

DOF (Diario Oficial de la Federación) 2010. Norma Oficial Mexicana NOM-059-Semarnat, México, D.F.

Dransfield J., Uhl N.W., Asmussen C.B., Baker W.J., Harley M.M. \& Lewis C.E. (2008). Genera Palmarum: The Evolution and Classification of Palms. London, UK: Kew Publishing-Royal Botanic Gardens.

Galeano G. \& Bernal R. (2010). Palmas de Colombia. Guía de Campo. Bogotá, Colombia: Universidad Nacional de Colombia.

Martínez-Ballesté A., Martorell C. \& Caballero J. (2008). The effect of Maya traditional harvesting on the leaf production, and demographic parameters of Sabal palm in the Yucatán Peninsula, Mexico. Forest Ecology and Management 256, 1320-1324.

Miranda F. (1958). Estudios acerca de la vegetación [de la Península de Yucatán]. En: Beltrán E. Ed. Los Recursos Naturales del Sureste y su Aprovechamiento, Tomo II. pp. 215-271. México, D.F.: Instituto Mexicano de Recursos Naturales Renovables, A.C.

Orellana R. (1992). Síndromes morfológicos y funcionales de las palmas de la Península de Yucatán. Bulletin de l'Institut Francais d' Etudes Andines 21, 651-667.

Orellana R., Herrera P., Rebollar S., Escalante J., López G., Escalante S. \& Gus L. (1999). Studies on the potential uses of some native palms of the Yucatan Peninsula (Mexico) as substitutes of Rattan. Acta Horticulturae 486, 291-295.

Pérez-Sarabia, J.E. R. Duno de Stefano, G. Carnevali Fernández-Concha, I. Ramírez Morillo, N. MéndezJiménez, P. Zamora-Crescencio, C. Gutiérrez-Báez, \& W. Cetzal-Ix. (2017). El conocimiento florístico de la Península de Yucatán, México. Polibotánica 44, 39-49.

Pérez-García M. \& Rebollar-Domínguez S. (2008). Formas de aprovechamiento de algunas palmas de la Península de Yucatán. Contactos 69, 53-60.

Pulido Silva M.T. \& Caballero Nieto J. (2011). Uso de la palma de huano. En: Ozo, G., Armijo Canto, N. Y Calmé, S. Editoras. Riqueza Biológica de Quintana Roo. Un análisis para su conservación. Tomo I. pp. 157-160. México, D. F.: El Colegio de la Frontera Sur (ECOSUR), Comisión Nacional para el Conocimiento y Uso de la Biodiversidad (CONABIO), Gobierno del Estado de Quintana Roo y Programa de Pequeñas Donaciones (PPD).

Quero H. \& Flores J.S. (2004). Arecaceae: Taxonomía, Florística y Etnobotánica. Etnoflora Yucatanense: 23. México: Universidad Autónoma de Yucatán, Yucatán.

Sánchez S.O. \& Islebe G.A. (2002). Tropical forest communities in southeastern Mexico. Plant Ecology 158, 183-200.

SEMARNAT. (1997). Norma Oficial Mexicana NOM-006-SEMARNAT-1997, Procedimientos, criterios y especificaciones para realizar el aprovechamiento, transporte y almacenamiento de hojas de palma. Diario Oficial de la Federación 28 de mayo 1997.

SEMARNAT. (2012). Plan de manejo tipo para palma chit (Thrinax radiata), manejo extensivo para la conservación y aprovechamiento sustentable. Ciudad de México: Secretaría de Medio Ambiente, Recursos Naturales y Pesca. 